\title{
A Colletes hederae Schmidt \& Westrich, 1993, (Hymenoptera: Colletidae) a hazai fauna új tagja
}

\author{
Voigt Wilfried $^{1} \&$ Szalai-Dobosné Márta Mária ${ }^{2}$ \\ ${ }^{1}$ H-7030 Paks, Fenyves u. 1., Hungary, email: voigtwilly@gmail.com \\ ${ }^{2} \mathrm{H}-7030$ Paks, Kurcsatov u. 11., Hungary
}

Voigt, W. \& Szalai-Dobosné MáRta, M.: First occurrence of Colletes hederae Schmidt \& Westrich, 1993 (Hymenoptera: Colletidae) in Hungary.

Abstract: During the fieldwork at Felsöörs Szent Kereszt hill in the beginning of May of 2016, the authors found a small nesting aggregation of the ivy bee, Colletes hederae (Schmidt \& Westrich, 1993). It is the first occurence of the near past described species in Hungary. For a second time, the authors detected pollencollecting females of the species at the end of September in 2019, in Balatonalmádi on ivy (Hedera helix). Present study discusses the characteristics of the species, and summerizes its relationship within the Colletes succinctus group.

Keywords: bee, new records, faunistics, Hungary.

\section{Bevezetés}

A népes, Ausztrália, Madagaszkár és Délkelet-Ázsia kivételével világszerte, de főleg az északi féltekén elterjedt Colletes (Hymenoptera: Colletidae: selyemméhek) genusznak mintegy 60 faja él Európában [1]. Közép-Európában német nyelvterületen (Németország, Ausztria, Svájc) 21 fajuk fordul elő [2], Magyarországról 19 faj ismeretes (JózAN 2011).

2016. szeptember elején a Felsőörstöl Lovasig húzódó Malom-völgy (Veszprém megye, Balaton-felvidék) florisztikai-faunisztikai terepbejárása során, a völgyvonulat keleti lejtőjét egy szakaszon határoló Szent Kereszt-hegy (Felsőörs) meredek, délnyugati letörésén Szalai-Dobosné felfigyelt a talajközelben rajzó-nászrepülő selyemméhekre. Ezek közeli behatóbb tanulmányozása során az első szerző már a helyszínen megállapította, hogy - föleg a nőstényeknél szembetünően - habitusuk eltér az ilyenkor a térségben még aktív Colletes fajokétól. Az állatokról fényképes dokumentációt készítettük. 


\section{Anyag és módszer}

A Malom-völgy alsóbb, patakközeli lejtöit üde gyertyános-kocsánytalan tölgyesek borítják, e fölött pedig, triász mészkövön, szárazabb cseres-kocsánytalan tölgyesek teremnek, átmenetekkel a sziklakibúvásos-gyepfoltos karsztbokrosodás felé. A selyemméhek is egy ilyen helyen, suvadásos, meredek lejtörészbe ásták, itt vízszintes bejáratú fészeküregeiket.

A következő napokban, a világhálón található vadméhes szakoldalak tanulmányozása során, és a taxonról készített fényképeinket az ezen szakoldalak fotóanyagával összevetve, kétséget kizáróan kiderült, hogy ez a Colletes hederae (Schmidt \& Westrich, 1993) [1], [2], [3], [4]. Mivel JózAN (2011) listájában e faj nem szerepel, a világhálós keresés sem eredményezett rá magyar találatot, és a fenti, külföldi szakoldalokon felsorolt, elöfordulási rekorddal rendelkező országok közt sem szerepel Magyarország, jelen észlelés egyben e faj első kimutatása Magyarországról.

2019. szeptember végén a szerzőpáros, nem kis meglepetésére, Balatonalmádi (Veszprém megye, Balaton-felvidék) egyik belterületi kertes telkén újra találkozott a Colletes hederae fajjal, ahol e selyemméh néhány, már kissé kifakuló nősténye a kerítésre felfutott borostyán virágzatain pollent gyüjtött. Az esetet szintén fotókkal dokumentáltuk.

\section{Eredmények és megvitatás}

\section{Colletidae}

Colletes hederae (Schmidt \& Westrich, 1993) - Felsöörs: Szent Kereszt-hegy 2016. IX. 04. fészektelep rajzó-nászrepülő egyedekkel; Balatonalmádi: belterületi zártkert 2019. IX. 23. Hedera helix L. virágzatain több pollengyüjtő nőstény - Magyarország faunájára új!

A faj csak viszonylag későn, az 1990-es évek elején vált ismertté (SchmidT \& WeSTRICH 1993). Ebben bizonyára közrejátszott, hogy a fö tápnövénye - ami ebben az esetben, rendhagyó módon, a fajleírás legfőbb indoka volt - a közönséges borostyán (Hedera helix) a természetes élőhelyein csak a méhkutató számára elérhetetlen magasságban virágzik, fák (legtöbbször tölgyek) koronaközeli szintjén. Azon kívül, ahogy azt más szerző hozzáteszi [2], a vadméhkutatók októberre (amely hónap nyugaton a borostyán fő virágzási ideje) rendszerint már befejezik a terepi kutatómunkájukat. A faj közzététele elött előkerült példányokat különböző kutatók hol a Colletes succinctus (Linné, 1758), hol a Colletes halophilus (Verhoeff, 1944) fajnak tartották, amint az a revízióknál kiderült.

Nöstény: 8,5-14,5 mm; feje világos barna szörös, fejpajzsa elöl harántráncos; tora barna bundás, oldalt világosabb; potroha kúpos, végén darázsszerüen hegyesedő, fényes fekete; minden hátlemez széles, friss példányoknál karamellszínűen sárgásbarna hátulsó szőrszalaggal. A tor felőli részén barna szőrös első hátlemeznek csak oldalt van szalagja, a második tergitnek van töszalagja is.

Hím: 8,5-12,5 mm; fejpajzsa harántráncok nélküli; potroha karcsúbb-hengeresebb, nem hegyesedő, kevésbé fényes, világosabb, osztatlan végszalagokkal, hatodik haslemezén a pereme elött két gödröcskével, valamint élgerinccel [2], [4]. 


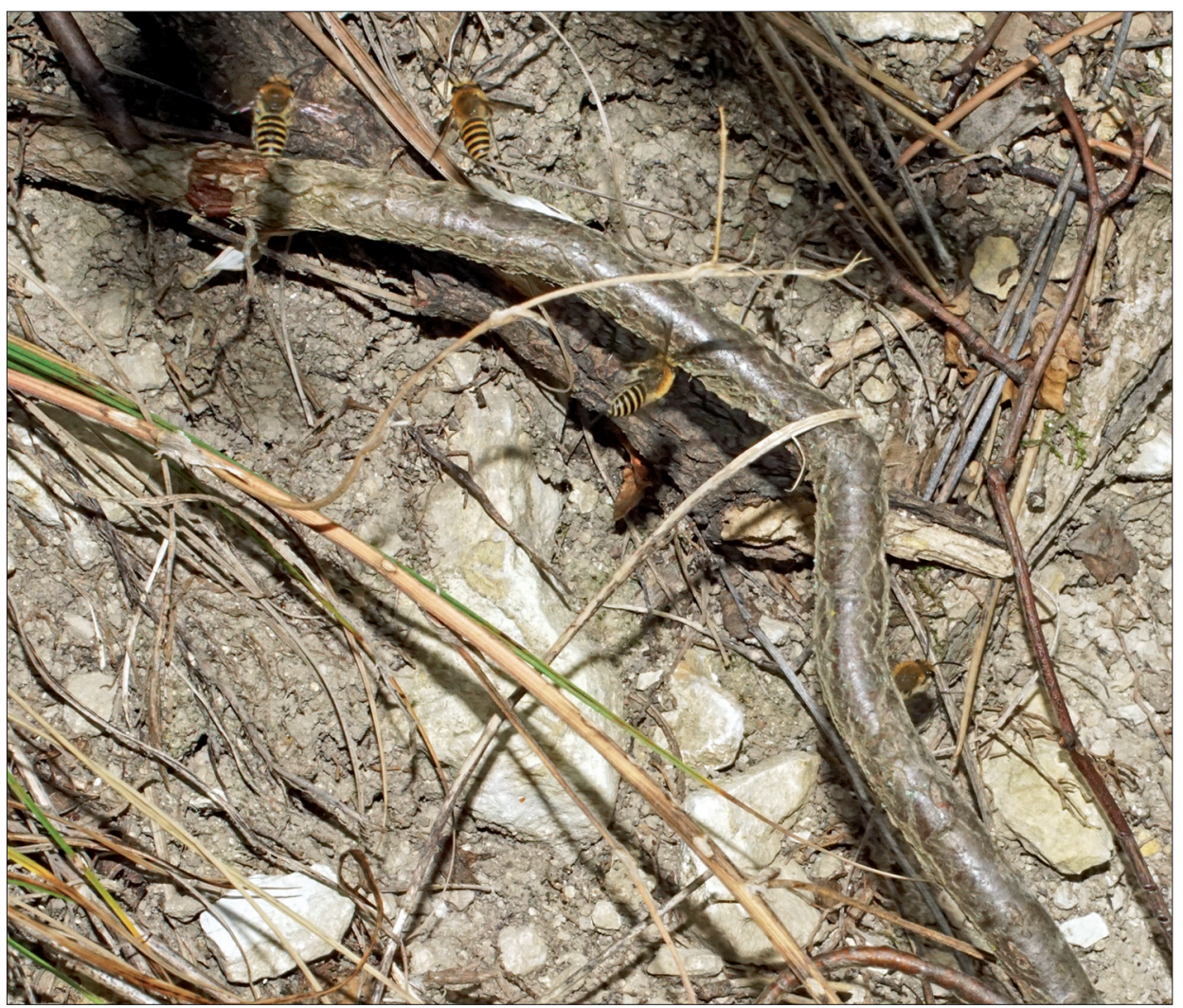

1. ábra: Colletes hederae rajzás, Felsőörs: Szent Kereszt-hegy Fotó: Szalai-Dobosné Márta Mária

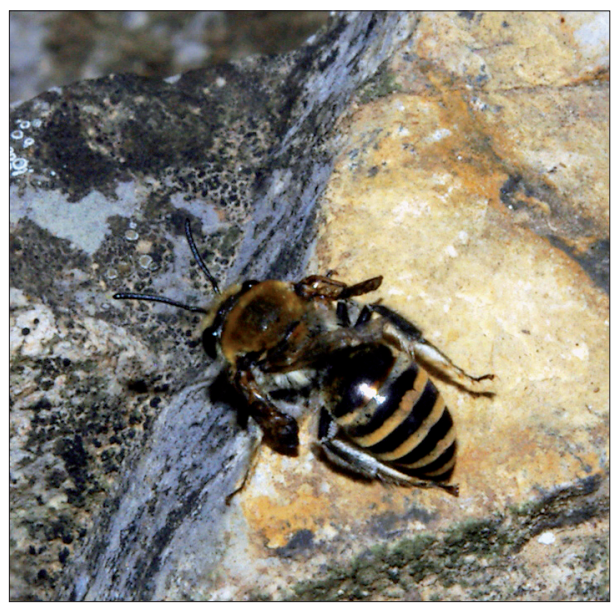

2. ábra: Colletes hederae nőstény, Felsöörs: Szent Kereszt-hegy Fotó: Voigt Wilfried

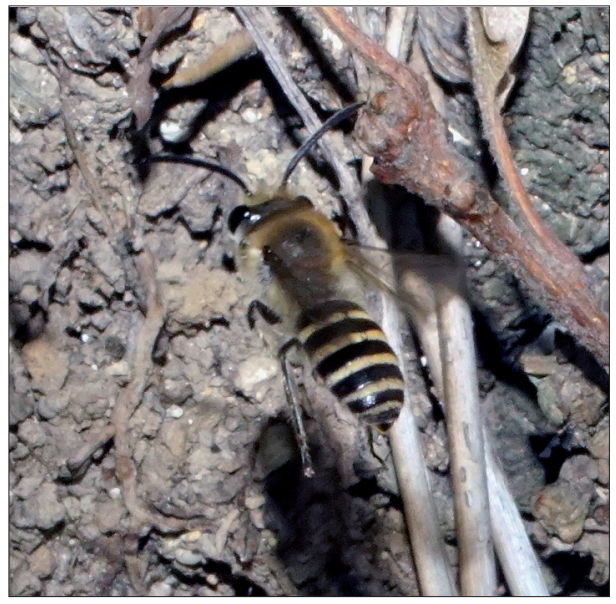

3. ábra: Colletes hederae hím, Felsőörs: Szent Kereszt-hegy Fotó: Szalai-Dobosné Márta Mária 


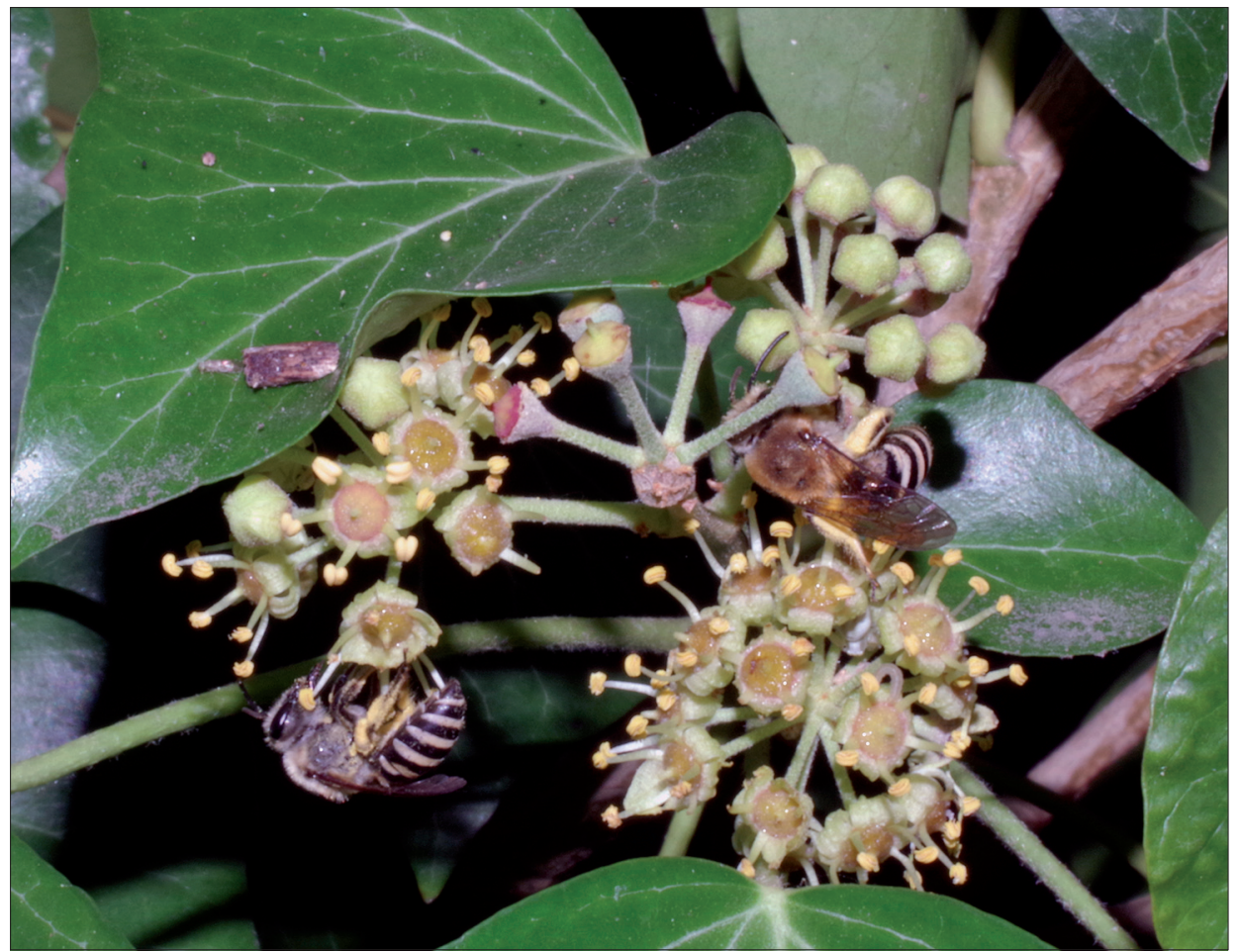

4. ábra: Colletes hederae nőstények borostyánon, Balatonalmádi: zártkert Fotó: Voigt Wilfried

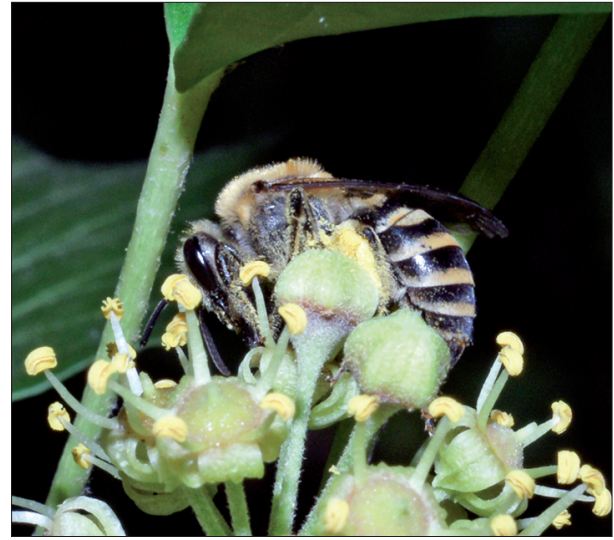

5. ábra: Colletes hederae nőstény borostyánon, Balatonalmádi: zártkert Fotó: Szalai-Dobosné Márta Mária

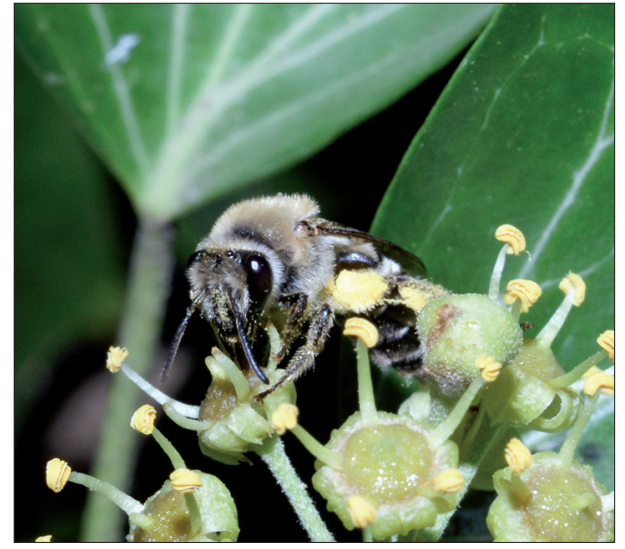

6. ábra: Colletes hederae nőstény borostyánon, Balatonalmádi: zártkert Fotó: Szalai-Dobosné Márta Mária 
Elterjedés: Vélhetőleg megegyezik a fő tápnövénye, a közönséges borostyán, (Hedera helix) előfordulási területével (KuHLMANN et al. 2007). Jelenleg ismert areája NyugatKözép-Európa. A következő országokból voltak eddig adatai: Spanyolország (Pireneusok.), Franciaország (Korzikáról is ismert), Olaszország (Appenninek és Szardínia), Belgium, Hollandia, Nagy-Britannia (első adata Dél-Anglia: Dorset, 2001; jelenleg Cumbria: 2018.), Csatorna-szigetek, Luxemburg, Németország (1993 FelsőRajna, dél felől terjeszkedőben: 2013 Solingen), Svájc, Szlovénia, Horvátország, Szerbia, Görögország, Ciprus. [1], [2], [4].

Élőhely: bár egyes források hangsúlyozzák a lösz- és homoktalajt [1], [2], de valószínüsíthető, hogy e tekintetben nem válogatós. Találtak már fészekkolóniákat füves lejtőkön, tengerparti szirteken, útpadkán és kertekben [4].

Szaporodás-biológia: Univoltin, a talajon telepesen fészkelö, proterandrikus faj, amely pihenőlárvaként áttelel. A nőstények repülési ideje szeptember elejétől általában október végéig tart, időjárási viszonyok függvényében november elejéig is. A hímek a kora ősz beköszöntével, már augusztus legvégén megjelennek, és az üregeknél várják a néhány nappal később kirajzó nőstényeket. A heves násztevékenység során megtermékenyített nőstények a saját maguk ásta, és egy selyem- vagy celofánszerü (igazi poliészter [1]) mirigyváladékkal beborított és azon felül egy másik, gomba- és baktériumellenes mirigyváladékkal impregnált [2] talajbéli fészeküregbe helyezik a nektár- és pollencsomaggal ellátott petét.

Paraziták: A Nyugat-Európából jelzett parazitái (Epeolus cruciger és E. fallax nemezméhek, Stenoria analis élősdibogár [2]) közül Magyarországon csak az Epeolus cruciger (Panzer, 1799) fordul elő (JózAN 2011).

Táplálkozás: Az elsősorban a közönséges borostyán (Hedera helix) prefernciája miatt leírt, akkor monolektikusnak tartott fajról mára kiderült, hogy valójában polilektikus taxon, erős borostyán preferenciával. $C$. hederae nőstények által a borostyán virágba borulása elött gyüjtött pollenrakományokon végzett vizsgálatok Colchicum autumnale, Odontites lutea, Solidago canadensis és S. gigantea, Calluna vulgaris pollent mutattak ki. [2]. Érdekes, hogy a méh még a rendelkezésre álló borostyánt sem mindig részesíti elönyben. Svájcban, Olaszországban és Franciaországban vizsgált pollenrakományok Hedera pollen mellett részben vagy túlnyomó részben Odontites és Calluna pollenből és néhány Asteraceae faj pollenjéből álltak [4]. 2015-ben kiderült a grázi (Ausztria) botanikus kertben vizsgált $C$. hederae nőstényekről, hogy pollenrakományuk egészen 98,5 \%-ig Rhus chinensis pollenből állt, a közvetlen közelben teljes virágzásban lévő borostyán ellenére [2].

C. hederae hímek elsősorban ernyősökön (Apiaceae) és fészkeseken (Asteracea) táplálkoznak [2], [4].

A selyemméhek terepi, illetve az ott készült fényképek alapján történő, beazonosítása még egy specialista számára sem egyszerü, ez leginkább nőstények esetén sikerülhet. A fajok biztos elkülönítése a galea vésezettségének vizsgálata nélkül nem lehetséges. Nem könnyíti meg a helyzetet az a tény sem, hogy a borostyán selyemméh genuszának legkésőbb rajzó tagja, mivel rajzásának első szakasza átfedésben lehet egyes gyakori rokonaival, nevezetesen Colletes daviesanus (Smith, 1846), Colletes fodiens (Geoffroy in Fourcroy, 1785), Colletes similis (Schenck, 1853) rajzásának végével. E fajok ilyenkor éppúgy előszeretettel gyüjtenek-táplálkoznak fészkeseken, például Solidago fajokon, mint borostyánvirágzás előtt a $C$. hederae nőstények. Utóbbiak viszont kifejezetten nagy, sokszor háziméhnél is termetesebb állatok, és még hímjei is nagyobbak előbbi három faj 10-11 mm-es nőstényeinél. Továbbá, a fenti fajok tergitszalagjai friss állapotban is fehérek, nem sárgásbarnák és keskenyebbek a $C$. hederae fajénál. E két bélyeg - a nagy méret és a széles tergitszalag - még akkor is segíti az azonosítást, ha idősebb korú, 
kifakult borostyán selyemméhre akadunk. A szerzők által még nem látott $C$. succinctus is kisebb (nősténye 10-12 mm), keskeny, fehér tergitszalagokkal. Rajzásának csúcsa augusztus végére esik, de a vége szintén átfedésben van a $C$. hederae rajzásával, mely utóbbinál a csúcs egy hónappal későbbre, szeptember végére esik ([2]; KuHLMANN et al. 2007).

Kuhlmann et al. (2007) szerint a legalább 12 fajú C. succinctus csoportnak három tagja fordul elő Európa nyugatibb részén, a Colletes succinctus (Linné, 1758) mellett a Colletes halophilus (Verhoeff, 1944) és a Colletes hederae (Schmidt \& Westrich, 1993), míg két további faja, a Colletes brevigena (Noskiewicz, 1936) és a Colletes collaris (Dours, 1872) Európa délebbi régióiban szórványos. Ezek közül Magyarországról eddig a Colletes succinctus és a Colletes collaris volt ismert (JózAN 2011). Genetikai vizsgálatokkal kiderítették, hogy fenti csoport elsőnek említett három faja a többi Colletes fajtól elkülönülö, szoros rokonságot alkot. Együttesen csak a La Manche-csatorna mentén fordulnak elö. Számos vizsgálati eredmény vall arra, ahogy azt KuHLMANN et al. (2007) a végső konklúziójukban valószínüsítik, hogy a $C$. halophilus és a $C$. hederae csak viszonylag későn különült el a $C$. succinctus taxontól. A három faj közül ennek a legnagyobb az elterjedése (Portugália - Kazahsztán), amely terület - ellentétben a másik két taxontól - leginkább fedésben van preferált pollenforrásának (Ericaceae: Calluna, Erica) areájával. Egyes populációiban és bizonyos körülmények mellett a $C$. succinctus nőstényei Hedera vagy Asteraceae pollen gyüjtésére hajlanak, melyek a $C$. hederae, illetve a $C$. halophilus jellemző pollenforrásai. Magyarországon a $C$. succinctus elterjedése: Alföld, Dunántúli-dombság, Dunántúli-középhegység, Nyugat-magyarországi peremvidék (JózAN 2011). E régiók közül a méh preferált pollennövényének, a csarabnak (Calluna vulgaris) csak az ország nyugati részén van szórványos előfordulása, a többi régióból majdnem vagy teljesen hiányzik [5]. Csarab helyett Magyarországon Papp Jenő és Józan Zsolt a következő pollenforrás növényekről gyüjtötték a C. succinctus fajt: Acinos arvensis, Origanum vulgare, Stachys annua, Dipsacus laciniatus, Tripleurospermum inodorum valamint a nyár végén Solidago gigantea fajon (Józan Zsolt ex litt. 2019. 10. 03.).

\section{Irodalom}

JózAN, Zs. 2011: Checklist of Hungarian Sphecidae and Apidae species (Hymenoptera, Sphecidae and Apidae). - Natura Somogyiensis 19: 177-200.

Kuhlmann, M., Else, G. R., Dawson, A., Quicke, D. L. J. 2007: Molecular, biogeographical and phenological evidence for the existence of three western European sibling species in the Colletes succinctus group (Hymenoptera: Apidea). - Organisms Diversity \& Evolution 7(2): 155-165.

Schmidt, K. \& Westrich, P. 1993: Colletes hederae n. sp., eine bisher unerkannte, auf Efeu (Hedera) spezialisierte Bienenart (Hymenoptera: Apoidea). - Entomologische Zeitschrift 103: 89-112.

\section{websites}

[1] https://en.wikipedia.org/wiki/Colletes (Accessed: 2019. 09. 28.)

[2] Seidenbienen Colletes. http://www.wildbienen.de/wbspeabc.htm (Hozzáférés: 2019. 09. 28.)

[3] http://www2.pms-lj.si/andrej/colhed.htm (Accessed: 2019. 09. 28.)

[4] https://www.bwars.com/bee/colletidae/colletes-hederae (Accessed: 2019. 09. 28.)

[5] http://floraatlasz.uni-sopron.hu/index.php?map (Accessed: 2019. 10. 04.) 